\title{
PENGARUH IMPLEMENTASI MODEL PEMBELAJARAN PROBLEM SOLVING DIPADUKAN DENGAN KETERAMPILAN HOTS TERHADAP HASIL BELAJAR PESERTA DIDIK BERDASARKAN STUDI LITERATUR
}

\section{THE EFFECT IMPLEMENTATION OF PROBLEM SOLVING LEARNING MODELS COMBINED WITH HOTS SKILLS ON STUDENT LEARNING OUTCOME BASED ON LITERATURE STUDY}

\author{
Hani'am Mari'a dan Ismono* \\ Jurusan Kimia FMIPA Universitas Negeri Surabaya \\ e-mail : $\underline{\text { ismono@unesa.ac.id }}$
}

\begin{abstract}
Abstrak
Artikel ini disusun dengan tujuan untuk mengetahui pengaruh implementasi model pembelajaran problem solving terhadap hasil belajar peserta didik jika dipadukan dengan keterampilan HOTS berdasarkan studi literatur. Studi terdahulu mengungkapkan bahwa keterampilan HOTS peserta didik tergolong rendah. Guru berperan penting memberikan inovasi baru disetiap kegiatan pembelajaran salah satunya yaitu dengan memilih model pembelajaran yang tepat, karena model pembelajaran yang diterapkan guru akan berpengaruh terhadap hasil belajar peserta didik. Hasil belajar merupakan faktor penting dalam proses pembelajaran karena menjadi salah satu tolak ukur keberhasilan pendidikan. Model pembelajaran yang cocok dengan keterampilan HOTS salah satunya yakni model pembelajaran problem solving. Penelitian ini dikaji melalui metode meta analisis dengan mengumpulkan beberapa data dari studi literatur penelitian yang setema. Hasil analisis studi literatur menyatakan bahwa model pembelajaran problem solving berpengaruh terhadap hasil belajar peserta didik dalam meningkatkan keterampilan HOTS dibuktikan dengan nilai posttest yang diperoleh peserta didik dengan rata-rata peningkatan nilai posttest peserta didik sebesar $22,87 \%$. Berdasarkan data yang telah dipaparkan pada pembahasan dapat disimpulkan bahwa implementasi model pembelajaran problem solving jika dipadukan dengan keterampilan HOTS dapat memberikan pengaruh terhadap hasil belajar peserta didik serta dapat meningkatkan motivasi belajar peserta didik.
\end{abstract}

Kata kunci: Problem Solving, Keterampilan HOTS, Hasil Belajar, Studi Literatur

\begin{abstract}
This article was prepared with the aim of knowing the effect of implementing a problem solving learning model on student learning outcomes when combined with HOTS skills based on literature studies. Previous studies revealed that students' HOTS skills were low. The teacher plays an important role in providing new innovations in every learning activity, one of which is by choosing the right learning model, because the learning model applied by the teacher will affect the learning outcomes of students. Learning outcomes are an important factor in the learning process because they are one of the benchmarks for the success of education. One of the learning models that match HOTS skills is the problem solving learning model. This research was examined through a meta-analysis method by collecting some data from a similar research literature study. The results of the literature study analysis stated that the problem solving learning model had an effect on student learning outcomes in improving HOTS skills as evidenced by the posttest scores obtained by students with an average increase in students' posttest scores by $22.87 \%$. Based on the data that has been presented in the discussion, it can be concluded that the implementation of problem solving learning models when combined with HOTS skills can have an effect on student learning outcomes and can increase students' learning motivation.
\end{abstract}

Keywords: Problem Solving, HOTS Skills, Learning Outcomes, Literature Study 


\section{PENDAHULUAN}

Pendidikan adalah upaya dalam mewujudkan proses dan suasana belajar dengan tujuan mengembangkan potensi peserta didik [1]. Peserta didik dituntut lebih aktif atas potensi dirinya guna menyesuaikan dengan tuntutan kurikulum yang berlaku.

Indonesia saat ini menerapkan kurikulum 2013. Implemetasi kurikulum 2013 memakai tiga aspek yakni pengetahuan, keterampilan, dan sikap [2]. Berdasarkan tiga aspek tersebut peserta didik akan mengalami keseimbangan antara kemampuan menjadi orang baik dan beretika.

Peran aktif peserta didik dibatasi saat proses pembelajaran di sekolah, padahal peran aktif dapat meningkatkan salah satu keterampilan peserta didik yaitu keterampilan HOTS. Proses pembelajaran berguna untuk mengembangkan pola pikir peserta didik menjadi individu yang kritis dan kreatif [3].

Indonesia secara khusus melalui revisi Kurikulum 2013, ditekankan pengintegrasian HOTS dalam pembelajaran. Heong menyatakan bahwa keterampilan HOTS ialah aspek penting dalam proses pembeljaran dan dapat mempengaruhi kemampuan, kecepatan, serta efektivitas belajar peserta didik [4]. HOTS adalah bekal masa depan peserta didik yang berupa kompetensi strategis dan penalaran adaptif dalam memecahkan masalah di kehidupan sehari-hari, sehingga hal tersebut menjadi aspek penting untuk implementasi Kurikulum 2013, serta menjadi kebutuhan dalam menyiapkan generasi abad 21 [5].

HOTS ialah proses berpikir yang membutuhkan kemampuan kognitif lebih tinggi dibandingkan hanya sekedar recall, restate atau recite [6]. Keterampilan berpikir tingkat tinggi juga didefinisikan sebagai proses berpikir yang bertujuan utnuk menghasilkan solusi dalam situasi yang rumit dan membingungkan. Taksonomi Bloom membagi keterampilan berpikir tingkat tinggi kedalam tiga tingkatan yakni menganalisis (C4), mengevaluasi (C5), dan mencipta (C6). Proses kognitif yang digolongkan sebagai berpikir kritis (critical thinking) yaitu menganalisis dan mengevaluasi, sedangkan mencipta tergolong berpikir kreatif (creative thinking) [7].
HOTS bertujuan meningkatkan kemampuan berpikir peserta didik, serta membuat keputusan pada situasi-situasi kompleks [8]. Keterampilan HOTS bermanfaat untuk menjadi referensi guru dan peneliti di masa mendatang [9].

Mayoritas guru paham akan keterampilan HOTS yang berarti guru harus melibatkan peseta didik secara langsung dalam pembelajaran [10]. HOTS meliputi keterampilan berpikir yang membutuhkan lebih dari sekadar mengingat atau menghafal informasi [11]. Peran guru sebagai fasilitator dalam pembelajran diharapkan dapat meningkatkan kemampuan peserta didik serta mendorong untuk berpikir secara luas dan mendalam [12]. Guru memiliki peran penting dalam memberikan inovasi pada pelaksanaan kegiatan pembelajaran dengan cara ketepatan pemilihan model pembelajaran, dikarenakan berpengaruh terhadap hasil belajar peserta didik yang menjadi faktor penting dalam proses pembelajran yakni sebagai tolak ukur keberhasilan pendidikan [13].

HOTS dapat membuat peserta didik terlatih dalam menyelesaikan suatu permasalahan, sehingga ketika seorang peserta didik lulus dari tingkat pendidikan maka peserta didik tersebut akan siap menghadapi tantangan yang lebih besar [14]. Perkembangan abad ke-21 pendidikan dibutuhkan dalam mempersiapkan peserta didik agar dapat menjalani tuntutan hidup, yaitu dibekali oleh keterampilan memecahkan masalah [15]. Model pembelajran yang cocok dipadukan dengan keterampilan HOTS salah satunya yakni model problem solving (pemecahan maslaah) [16].

Model problem solving ketika dihadapkan dengan situasi pertanyaan ataupun masalah, peserta didik dapat menalar dan mencari solusi untuk memecahkan masalah tersebut dengan mengembangkan pola pikirnya. Peserta didik tidak hanya dituntut untuk menghafal tanpa berpikir, tetapi dilatihkan untuk memecahkan suatu masalah serta mencari solusi secara spontan sehingga dapat memperluas proses berpikir [17].

Model ini dapat menuntut siswa berpikir dengan mengembangkan kemampuan yang dalam dirinya untuk meningkatkan hasil belajar baik berhubungan dengan materi pelajaran maupun lingkungan sekitar. Hasil belajar merupakan tolak 
ukur kemampuan peserta didik untuk mengetahui tingkat keberhasilan metode pembelajaran yang digunakan. Ketika seorang guru berhasil menerapkan suatu model pembelajaran dan menciptakan suasana belajar yang nyaman maka akan berpengaruh terhadap peningkatan hasil belajar peserta didik.

Riset ini bertujuan untuk mengetahui pengaruh implementasi model pembelajaran problem solving terhadap hasil belajar peserta didik jika dipadukan dengan keterampilan HOTS. Berdasarkan tujuan tersebut, peneliti melakukan analisis dengan menggunakan data sekunder yang dikutip dari beberapa jurnal yang setema dengan kata kunci "Problem Solving" dan "Higher Order Thinking Skills" yang kemudian dilakukan pengambilan data pretest dan posttest dalam bentuk nilai. Dalam artikel ini yang menjadi fokus tujuan akhir yakni hasil belajar peserta didik. Jika hasil belajar peserta didik dari nilai pretest hingga posttest mengalami peningkatan maka dapat dinyatakan bahwa perpaduan model pembelajaran problem solving dengan keterampilan HOTS cocok jika diterapkan disekolah.

Data tersebut dianalisis berdasarkan perbandingan dengan bantuan meta analisis dan hasil penelitian dalam jurnal akan dikaitkan dengan studi literatur penguasaan teori. Metode meta analisis merupakan metode yang dilakukan oleh peneliti dengan cara merangkum, mereview, dan menganalisis data dari beberapa peneliti terdahulu lalu diolah menggunakan Statistical Product and Service Solutions (SPSS) sehingga diperoleh data statistik sebagai data sekunder.

\section{DASAR TEORI}

\section{Problem solving}

Fokus pendidikan adalah mengajar siswa untuk berpikir, menggunakan kekuatan rasional, dan menjadi pemecah masalah [18].

Problem solving merupakan cara berpikir ilmiah dalam membuat suatu penyelesaian masalah [19]. Problem solving yaitu berpikir untuk menyelesaikan masalah dengan cara menalar [20]. Problem solving merupakan suatu penyelesaian masalah autentik dengan tujuan untuk menyusun pengetahuan mereka sendiri [21]. Problem solving dalam penelitian ini menekankan pada berpikir untuk menyelesaikan permasalahan autentik yang disajikan. Berikut empat langkah pemecahan masalah, yaitu [22]:

\section{a. Understood the problem}

Peserta didik tidak akan mampu menyelesaikan masalah tanpa adanya pemahaman.

b. Device a plan

Masalah yang telah dipahami akan memudahkan peserta didik menyusun rencana penyelesaian masalah.

c. Carry out the plan

Penyelesaian masalah harus sesuai dengan rencana yang tepat berdasarkan rencana awal baik secara tertulis maupun tidak.

\section{d. Lock Back}

Melengkapi pemecahan masalah dan mereview serta mendiskusikan pemecahan masalah yang telah dilakukan.

Peserta didik berhasil memecahkan suatu masalah tertentu akan tetapi jika konteks masalah sedikit dirubah maka peserta didik akan kebingungan dan berujung kegagalan. Hal ini disebabkan karena budaya belajar konvensional yang didominasi dengan pemetaan konsep dan rumus semata [23]. Kemampuan pemecahan masalah penting ketika peserta didik mampu menelaah masalah dan menerapkan pengetahuannya ke dalam situasi baru sehingga masalah serumit apapapun dapat terselesaikan [24].

\section{High Order Thinking Skills (HOTS)}

Pendidikan didirikan dengan suatu tujuan yakni untuk mencapai keterampilan berpikir tingkat tinggi. Namun, tujuan ini tidak mudah untuk dicapai mengingat keterampilan berpikir tingkat tinggi memiliki banyak definisi yang melibatkan banyak kegiatan [25]. HOTS sebagai proses berpikir yang diperluas meliputi (1) mengidentifikasi masalah, (2) mengklarifikasi istilah penting, (3) mengevaluasi informasi relevan, (4) memecahkan masalah [26].

HOTS mencakup kemampuan berpikir logis, kritis, metakognitif, reflektif, dan kreatif [27]. HOTS dalam tiga kategori: (1) transfer informasi dan pengetahuan, (2) berpikir kritis, (3) pemecahan masalah. HOTS dalam kategori transfer informasi dan pengetahuan terjadi pada pembelajaran bermakna [28]. Pada pembelajaran bermakna, peserta didik tidak hanya dituntut 
mengingat, tetapi mengharuskan memahami serta dapat menerapkan pengetahuan yang sudah dipelajari [29]. HOTS dalam kategori berpikir kritis merupakan berpikir yang masuk akal dan fokus dalam memutuskan suatu hal [30]. HOTS dalam kategori pemecahan masalah membantu peserta didik menentukan sumber masalah dan menemukan solusi yang efektif. Fase dalam memecahkan suatu masalah terbagi menjadi empat, yaitu : memahami masalah, menyususn rencana solusi, melaksanakan rencana solusi, dan mengevaluasi solusi [22].

HOTS dapat berkembang dengan baik apabila dilakukan secara sengaja dan terencana melalui penerapan model pembelajaran dengan keterlibatan peserta didik secara aktif (student centered) [31]. HOTS dikatakan berhasil jika peserta didik terlibat langsung dengan informasi yang telah diketahui dalam pembeljaran kemudian mampu bernalar untuk memahami hal-hal yang kompleks [32].

Jika peserta didik mampu mengaitkan sebuah informasi baru dengan informasi yang sudah dimilikinya kemudian menata ulang informasi dan dikembangkan untuk menemukan penyelesaian dari suatu keadaan serta dapat terpecahkan maka kemampuan HOTS peserta didik dapat dikatakan sudah berkembang [33]. HOTS seringkali disepadankan dengan tiga jenjang kognitif tertinggi (top-three) dalam Taksonomi Bloom revisi yakni C4 (menganalisis); C5 (mengevaluasi); C6 (mencipta) [34].

\section{Hasil Belajar}

Faktor penting yang menjadi tolak ukur keberhasilan suatu proses pembelajaran yakni dapat ditinjau dari hasil belajar peserta didik. Hasil belajar merupakan bukti keberhasilan yang telah dicapai peserta didik. Dalam hal ini belajar meliputi keterampilan proses, keaktifan, motivasi, juga prestasi belajar peserta didik [35]. Hasil belajar pada hakikatnya berupa perubahan tingkah laku peserta didik yang umumnya dinilai diakhir pembelajaran sebagai hasil evaluasi [36]. Hasil belajar yang menjadi salah satu indikator pencapaian tujuan pembelajaran tidak terlepas dari faktor-faktor yang mempengaruhi, yakni sebagai berikut [37]: a. Faktor internal adalah faktor yang ada dalam diri peserta didik yang meliputi faktor jasmani dan faktor psikologis

b. Faktor ekternal adalah faktor yang ada diluar diri peserta didik yang meliputi faktor keluarga, faktor sekolah, faktor lingkungan masyarakat

Berdasarkan faktor-faktor yang dapat mempengaruhi hasil belajar peserta didik maka peneliti mereview beberapa artikel yang setema dengan cakupan yang sama yakni faktor eksternal berupa penggunaan model pembelajaran problem solving yang dipadukan dengan keterampilan HOTS untuk meninjau seberapa besar pengaruh dari penerapan model tersebut terhadap hasil belajar peserta didik.

\section{METODE}

Penelitian ini dikaji melalui metode meta analisis dengan mengumpulkan beberapa data dari studi literatur penelitian yang setema. Berdasarkan studi literatur yang dilakukan untuk memperoleh rata-rata nilai pretest dan posttest peserta didik yang kemudian diolah menggunakan metode SPSS dengan menggunakan uji paired samples untuk mengetahui peningkatan hasil belajar peserta didik.

Uji paired samples test adalah pengujian yang digunakan untuk membandingkan selisih dua mean dari dua sample (pretest dan posttest) yang berpasangan dengan asumsi data terdistribusi normal. menjelaskan rata-rata hasil pretest dan posttest peserta didik.

\section{HASIL DAN PEMBAHASAN}

Tujuan utama dari artikel ini adalah untuk merivew serta mengkaji beberapa literatur yang membahas tentang keterampilan HOTS jika dipadukan dengan model problem solving, dibuktikan dari hasil pretest dan posttest peserta didik, hasil diperoleh dari lima artikel yang setema dengan judul penelitian. Kemudian peneliti akan merata-rata hasil tersebut dan disajikan dalam bentuk data lalu dianalisis. Selanjutnya data diolah menggunakan Statistical Product and Service Solutions (SPSS) dengan uji paired samples lalu data diperkuat dengan tiga artikel yang setema. Data hasil analisis Keterampilan HOTS jika 
dipadukan dengan model pembelajaran problem

solving dapat dilihat pada Tabel 1 berikut:

Tabel 1. Presentase Peningkatan Hasil Belajar Peserta Didik dengan Model Problem Solving Dipadukan dengan Keterampilan HOTS.

\begin{tabular}{clccc}
\hline \multirow{2}{*}{ No. } & \multicolumn{1}{c}{ Pengarang } & \multicolumn{2}{c}{ Persentase (\%) } \\
& \multicolumn{1}{c}{ Pretest } & Posttest & Peningkatan \\
\hline 1 & Ria Mayasari. Rabiatul Adawiyah (2015)[38] & 65,00 & 78,21 & 13,21 \\
2 & Johnsen Harta (2017)[39] & 25,06 & 61,15 & 36,09 \\
3 & Bina Aulia Mahfuzah, Mahfuzah, Yudhi Utomo (2018)[40] & 70,00 & 80,28 & 10,28 \\
4 & Fitri Nisak, Gusnedi, Amalia Putra (2018)[41] & 35,70 & 46,40 & 10,70 \\
5 & Safri Daryanti, Indra Sakti, Dedy Hamdani (2019)[42] & 31,45 & 75,53 & 44,08 \\
& Rata - rata & 45,44 & 68,31 & 22,87 \\
\hline
\end{tabular}

Berdasarkan data dari Tabel 1 diketahui bahwa persentase hasil belajar peserta didik mengalami peningkatan, dibuktikan dengan ratarata sebelum diterapkan model problem solving (pretest) sebesar $45,44 \%$ dan setelah diterapkan model problem solving (posttest) menjadi $68,31 \%$ sehingga rata-rata peningkatan mencapai $22,87 \%$. Selanjutnya dicari uji normalitas masing-masing data sebagai berikut :

Tabel 2. Hasil Uji Normalitas Masing-Masing Artikel

\begin{tabular}{cccc}
\hline No & Pretest & Posttest & Signifikan \\
\hline 1 & 65,00 & 78,21 & 0,05 \\
2 & 25,06 & 61,15 & 0,93 \\
3 & 70,00 & 80,28 & 0,37 \\
4 & 35.70 & 46,40 & 0,14 \\
5 & 31,45 & 75,53 & 0,60 \\
\hline
\end{tabular}

Pada Tabel 2 masing-masing data dilakukan uji normalitas dan diperoleh hasil berupa nilai signifikan. Uji normalitas bertujuan untuk mengetahui apakah nilai residual (sampel) terditribusi normal atau tidak. Uji normalitas pada artikel ini menggunakan uji Liliefors. Model regresi yang baik yakni memiliki nilai residual yang terditribusi normal. Kategori yang menjadi dasar pengambilan keputusan apakah nilai residual tersebut terditribusi normal atau tidak yakni jika nilai signifikan lebih besar dari 0,05 ( $\alpha /$ taraf ketetapan) maka dapat dinyatakan bahwa nilai residual tersebut tersitribusi normal namun jika nilai signifikan lebih kecil dari 0,05 maka nilai residual tersebut tidak terditribusi normal. Berdasarkan hasil uji normalitas masing-masing artikel diketahui nilai signifikan lebih besar daripada 0,05 maka dapat disimpulkan bahwa semua data berada pada kategori terdistribusi normal. Selanjutnya hasil belajar peserta didik diolah menggunakan uji paired samples yakni paired samples statistics, paired samples correlations, dan paired samples test dan diperoleh data seperti pada Tabel 3, Tabel 4, dan Tabel 5 sebagai berikut:

Tabel 3. Paired Samples Statistics

\begin{tabular}{cccccc}
\hline & & Mean & N & Std. Deviation & Std. Error Mean \\
\hline \multirow{2}{*}{ Pair } & Pretest & 45,4420 & 5 & 20,56526 & 9,19706 \\
& Posttest & 68,3140 & 5 & 14,35908 & 6,42158 \\
\hline
\end{tabular}

Tabel 4. Paired Samples Correlations

\begin{tabular}{ccccc}
\hline & N & Correlation & Significant \\
\hline Pair & Pretest \& Posttest & 5 & 0,632 & 0,253 \\
\hline
\end{tabular}

Tabel 5. Paired Samples Test

\begin{tabular}{|c|c|c|c|c|c|c|c|c|c|}
\hline & & Mean & $\begin{array}{c}\text { Std. } \\
\text { Deviation }\end{array}$ & $\begin{array}{l}\text { Std. } \\
\text { Error } \\
\text { Mean }\end{array}$ & $\begin{array}{c}\mathbf{9 5 \%} \\
\text { Interval } \\
\text { Difference } \\
\text { Lower } \\
\end{array}$ & $\begin{array}{c}\text { Confidence } \\
\text { of the } \\
\text { Upper }\end{array}$ & $\mathbf{t}$ & df & $\begin{array}{l}\text { Sig. } \\
\text { tailed })\end{array}$ \\
\hline $\begin{array}{c}\text { Pair } \\
1\end{array}$ & $\begin{array}{l}\text { Pretest - } \\
\text { Posttest }\end{array}$ & $-22,87200$ & 16,00441 & 7,15739 & $-42,74410$ & $-2,99990$ & $-3,196$ & 4 & 0,033 \\
\hline
\end{tabular}


Tabel 3 diatas menunjukkan bahwa model problem solving jika dipadukan dengan keterampilan HOTS akan sangat cocok yang dibuktikan meningkatnya hasil belajar peserta didik dengan nilai rata-rata awal sebesar 45,4420 kemudian mengalami peningkatan hingga nilai rata-rata akhir mencapai 68,3140 .

Tabel 4 diatas menunjukkan bahwa terdapat korelasi antara nilai rata-rata sebelum dengan sesudah menerapkan model problem solving yang dipadukan dengan keterampilan HOTS dengan angka korelasi mencapai 0,632. Hasil uji hipotesis, $\mathrm{H}_{0}=$ tidak terdapat perbedaan yang signifikan oleh peserta didik sebelum atau setelah diterapkan pembelajaran dengan model problem solving yang dipadukan keterampilan HOTS dan $\mathrm{H}_{1}=$ terdapat perbedaan yang signifikan oleh peserta didik sebelum atau setelah diterapkan pembelajaran dengan model problem solving yang dipadukan keterampilan HOTS.

Tabel 4 ditunjukkan bahwa nilai signifikan antara pretes dan postes sebesar $(0,253)$ $>\alpha(0,05)$ yang berarti nilai signifikan tersebut tidak melampaui nilai ketetapan. Nilai tersebut dicocokkan dengan mencari besar nilai $\mathrm{T}$ tabel dalam buku metode statistik dengan t 0,975 dan dk 4 ditemukan nilai $\mathrm{T}$ tabel sebesar 2,78 [43].

Tabel 5 ditunjukkan bahwa hasil $\mathrm{T}$ hitung $(-3,196)<\mathrm{T}$ tabel $(2,78)$ maka $\mathrm{H}_{0}$ ditolak, jadi terdapat perbedaan signifikan dari hasil belajar peserta didik sebelum dan setelah diterapkan model pembelajaran problem solving yang dipadukan dengan keterampilan HOTS dalam sebuah pembelajaran.

Berdasarkan hasil yang diperoleh, peneliti menganalisis bahwa hasil perbedaan tersebut bisa terjadi disebabkan karena adanya faktor internal dan eksternal. Hal tersebut dipertegas oleh Hardi Tambunan, yang menyatakan bahwa banyak faktor yang mempengaruhi pencapaian HOTS seperti faktor internal dan eksternal [44]. Faktor internal yaitu minat dan motivasi siswa dalam belajar sedangkan faktor eksternal yaitu penggunaan pendekatan dan pelaksanaan pembelajaran [45]. Beberapa pendekatan yang dapat digunakan dalam pembelajaran, agar prestasi siswa dalam bidang HOTS dapat tercapai dengan baik, antara lain strategi pemecahan masalah yang dikembangkan oleh Polya, dan pendekatan saintifik [46].

Menurut peneliti salah satu contoh faktor internal yang menjadi penghambat meningkatnya hasil belajar peserta didik yakni perkembangan otak peserta didik yang perlu ditekanan terutama dizaman modern seperti sekarang ketika semua yang dibutuhkan bisa diakses atau diperoleh dengan mudah melalu kecanggihan teknologi yang ada namun kembali lagi ke bimbingan orang tua yang juga penting dalam mendidik anaknya diluar lingkugan sekolah. Bimbingan orang tua tersebut tergolong kedalam faktor eksternal yang erat kaitannya dengan faktor internal.

Faktor eksternal lain yang juga memepengaruhi meningkatnya hasil belajar peserta didik yakni dari latar belakang sekolah seperti sarana dan prasarana yang kurang memadai sehingga perkembangan otak peserta didik terbatas pada teori yang dikonsepkan oleh guru. Guru juga sangat jarang melakukan praktikum atau sekedar memberikan data lalu meminta peserta didik untuk menganalisis. Kebiasaan seperti ini yang kurang ditekankan di sekolah sehingga peserta didik banyak yang kurang pandai dalam menganalisis data ataupun menganalisis sebuah fenomena.

Pada perkembangan abad ke-21, peserta didik harus dibekali oleh sebuah keterampilan yang dapat mempersiapkan peserta didik tersebut untuk menjalani tuntukan hidup didunia pendidikan sebelum melangkah ke dunia kerja. Salah satu keterampilan yang wajib dikuasai oleh peserta didik sebagai dasar untuk melatih kemampuan yang dimiliki yakni keterampilan dalam memecahkan suatu masalah [15]. Ketika peserta didik mulai terlatih dalam keterampilan memecahkan masalah maka secara berangsur dan spontan peserta didik akan terbiasa dengan situasi yang membutuhkan akal pikiran yang lebih tinggi seperti keterampilan HOTS sehingga saat peserta didik lulus dari tingkat pendidikan, peserta didik mampu beradaptasi dengan lingkungan baru diluar dunia pendidikan [14]. Sistematika dalam pendidikan ketika seorang guru ingin mengembangkan potensi yang ada dalam diri peserta didik dengan tujuan melatihkan keterampilan tertentu misalnya keterampilan 
HOTS maka akan lebih tersampaikan kepada peserta didik jika guru melatihkan hal tersebut dengan menerapkan atau dipadukan oleh suatu model pembelajaran yakni model problem solving [16].

Model problem solving yaitu model pembelajaran yang diterapkan melalui pemecahan suatu masalah serta mencari solusi secara spontan sehingga dapat memperluas proses berpikir [17]. HOTS merupakan keterampilan yang dilatihkan untuk meningkatkan kemampuan berpikir peserta didik dalam membuat keputusan pada situasi kompleks [8]. Sehingga, model pembelajaran problem solving dapat menstimulasi peserta didik untuk memecahkan suatu masalah disajikan dalam bentuk fenomena kemudian peserta didik diminta untuk mencari sendiri solusi secara mandiri dalam pemecahan masalah. Jika dikaitkan dengan keterampilan HOTS yakni setelah peserta didik menemukan jawabannya secara mandiri maka jawaban tersebut harus dijabarkan berupa sebuah analisa yang ringkas dan mudah dipahami.

Peneliti menyimpulkan bahwa problem solving dapat melatihkan kemampuan berpikir tingkat tinggi dan lebih baik daripada dengan pembelajaran tradisional. Dalam penulisan artikel ini, peneliti juga mengaitkan hasil analisa tersebut dengan penelitian lain yang serupa yakni penelitian Hani Nabila, Ila Rosilawati, dan Nina Kadaritna tahun 2018 di SMAN Bandar Lampung dengan subjek penelitian yaitu kelas XI IPA 3 berisi penjelasan bahwa problem solving efektif dalam meningkatkan keterampilan HOTS peserta didik. Data membuktikan terdapat sebuah grafik interaksi antara model problem solving dengan keterampilan HOTS ditinjau dari kemamapuan akademik yang menujukkan garis tidak saling silang, maka dapat ditarik kesimpulan bahwa meningkatkan keterampilan HOTS peserta didik tidak dipengaruhi oleh kemampuan akademik, melainkan dipengaruhi oleh model pembelajaran problem solving. Hani Nabila, dkk juga melakukan uji ANOVA two ways n-gain terhadap keterampilan HOTS pada kategori model pembelajran dan dapat disimpulkan $\mathrm{H}_{0}$ ditolak, artinya model problem solving terbukti efektif meningkatkan keterampilan HOTS peserta didik [47].
Penelitian lain yang juga setema dan menjadi data dukung yakni penelitian Sardin dan Aep Sunendar pada tahun 2018 yang dilakukan di SMAN 2 Baubau Majalengka menggunakan kelas $X$ IPA dan hasilnya menunjukkan bahwa penerapan model problem solving memiliki pengaruh yang signifikan terhadap keterampilan HOTS. Berdasarkan hasil analisis deskriptif diperoleh gambaran keterampialn HOTS yang diterapkan meggunakan metode pembelajarn problem solving mendapatkan rata-rata nilai 45,54 yang berpatokan pada kriteria skor keterampilan HOTS maka dikategorikan baik yang berarti penerapan problem solving memiliki pengaruh signifikan terhadap keterampilan HOTS [48].

Penelitian terakhir yang juga memperkuat analisa dalam pengerjaan atikel ini yakni penelitian Waliyyatu Azzahra dan Heffi Alberida pada tahun 2020 yang dilakukan di SMAN 3 Bukittinggi memakai kelas $\mathrm{X}$ IPA 2 yang menjelaskan bahwa penerapan model pembeljaran problem solving memiliki pengaruh positif terhadap keterampilan HOTS peserta didik. Model problem solving mempunyai tahapan yang sistematis sehingga penelitian harus dilakukan dengan memahami secara rinci sintaks model tersebut. Dalam penelitinnya memperoleh nilai rata-rata keterampilan HOTS peserta didik setelah dianalisis menggunakan uji $\mathrm{T}$ di kelas tersebut diberi perlakuan berupa penerapan model problem solving dan diperoleh rata-rata nilai sebesar 73,02 [49].

Berdasarkan ketiga jurnal tersebut maka peneliti dapat menyimpulkan jika peserta didik diajar menggunakan penerapan model pembelajarn problem solving maka akan lebih mudah mengembangkan pola pikirnya karena dalam pembelajarn problem solving guru menyajikan masalah kepada peserta didik yang dirancang dalam bentuk pertanyaan atau pernyataan yang dikemas membentuk sebuah fenomena guna merangsang peserta didik berpikir sehingga peserta didik akan selalu terpicu dan terbiasa dalam menganalisis suatu masalah jika sedari awal guru menerapkan model pembelajaran berbasis masalah. Peserta didik secara bertahap akan mendorong kemampuan akademiknya secara mandiri dan akan terlatih dalam hal analisis baik 
data maupun masalah sehingga kedepannya peserta didik lebih mudah dalam menemukan solusi untuk menyelesaikan masalah yang ada dilingkungan secara mandiri.

Model problem solving memiliki langkahlangkah yang dapat mengasah keterampilan berpikir peserta didik. Jika peserta didik mencari sendiri solusi serta jawaban dari masalah yang dirancang guru maka peserta didik akan terpacu mengeluarkan seluruh kemampuan yang dimilikinya untuk menemukan jawaban dari masalah tersebut sehingga mempermudah peserta didik mengingat teori yang dipelajari. Hal ini sejalan dengan teori belajar Jeromy Bruner yang mengemukakan bahwa belajar adalah cara memilih, mempertahankan, dan mentransormasikan informasi secara aktif [50].

Implementasi dari model pembelajaran problem solving diharapkan dapat menciptakan lulus SMA yang siap terjun ke dunia kerja dengan dibekali penguasaan teori, sehingga memiliki daya saing intelektual yang tinggi [21]. Penelitian ini menunjukkan bahwa pembelajaran berbasis masalah akan menciptakan situasi belajar yang unik dan membingungkan sehingga membangkitkan keingintahuan peserta didik dan secara sadar melibatkan peserta didik untuk berpikir.

\section{SIMPULAN}

Berdasarkan pembahasan diatas dapat ditarik kesimpulan bahwa implementasi model pembelajaran problem solving jika dipadukan dengan keterampilan HOTS dapat memberikan pengaruh terhadap hasil belajar peserta didik dapat dilihat pada data peningkatan di Tabel 1 serta dapat meningkatkan motivasi belajar peserta didik karena jika dilihat dari hasil olah data menggunakan uji paired sample statistics, paired sample correlations, dan paired sample test maka implementasi model pembelajaran problem solving dinilai baik dan layak dalam meningkatkan kemampuan peserta didik guna meningkatkan keterampilan HOTS. Hal ini beracuan terhadap hasil belajar peserta didik dari beberapa artikel yakni lima artikel setema yang telah dikaji dan terbukti bahwa hasil belajar peserta didik mengalami peningkat yang signifikan dengan rata-rata peningkatan mencapai sebesar $22,87 \%$.

\section{DAFTAR PUSTAKA}

1. Depdiknas. 2003. Undang-Undang RI No. 20 Tahun 2003 Tentang Sistem Pendidikan Nasional. Jakarta: Depdiknas.

2. Permendikbud. 2014. Peraturan Menteri Pendidikan dan Kebudayaan Republik Indonesia Nomor 59 Tahun 2014 Tentang Kurikulum 2013 Sekolah Menengah Atas/ Madrasah Aliyah. Jakarta: Departemen Pendidikan dan Kebudayaan.

3. Aulia, Ernita Vika. 2015. Pengembangan Lembar Kerja Peserta (LKS) Berorientasi Inkuiri untuk Melatihkan Ketrampilan Berpikir Tingkat Tinggi Siswa pada Materi Ikatan Kimia Kelas X SMA Widya Dharma Surabaya. UNESA Journal of Chemical Education., Vol 4, No 2, pp. 163-171.

4. Heong, Y. M., Othman, W. B., Yunos, J. B. M., Kiong, T. T., Hassan, R. Bin, \& Mohamad, M. M. B. 2011. The Level of Marzano Higher Order Thinking Skills Among Technical Education Students. International Journal of Social Science and Humanity., Vol 1, No 2, pp. 121-125.

5. Herutomo, R. A. 2019. Pembelajaran Model Creative Problem Solving untuk Mendukung Higher-Order Thingking Skills Berdasarkan Tingkat Disposisi Matematis. Jurnal Riset Pendidikan Matematika., Vol 6, No 2, pp. 188-199.

6. Widana, I Wayan. 2017. Modul: Penyusunan Soal Higher Order Thinking Skills. Jakarta: Direktorat Pembinaan SMA.

7. Muslimin, Ibrahim. 2015. Berpikir Tingkat Tinggi (Higher Order Thinking). Jakarta: Seminar Pendidikan FMIPA Universitas Negeri Jakarta.

8. Saputra, Hatta. 2016. Pengembangan Mutu Pendidikan Menuju Era Global: Penguatan Mutu Pembelajaran dengan Penerapan HOTS (High Order Thinking Skills). Bandung: SMILE's Publishing.

9. Zohar, A. 2013. Challenges in Wide Scale Implementation Efforts to Foster Higher Order Thinking (HOTS) in Science Education Across a Whole Wide System. Thinking Skills and Creativity., Vol 10, No 1, pp. 233-249. 
10. Yen, T. S. 2015. Effective Teaching of Higher-Order Thinking in Eucation. Journal of Distance Eucation and E-Learning., Vol 3, No 2, pp. 41-47.

11. Ivie, S. D. 1998. Ausubel's Learning Theory: an Approach to Teaching Higher Order Thinking Skills. The High School Journal., Vol 82, No 1, pp. 35-42.

12. Nurhayani, Syamsudduha, St., \& Afiif A. 2018. Kesulitan Guru dalam Pengembangan Keterampilan Berpikir Tingkat Tinggi Siswa. Jurnal Biotek., Vol 6, No 1, pp. 93-111.

13. Underbakke, M., Borg, J. M., \& Peterson, D. 1993. Researching and Developing the Knowledge Base for Teaching Higher Order Thinking. Theory into Practice., Vol 32, No 3, pp. 138-146.

14. Khoiriyah, A. J. 2015. Problem Based Learning: Creative Thinking Skills, Problem Solving Skills and Learning Outcome of Seventh Grade Students. Jurnal Pendidikan Biologi Indonesia., Vol 4, No 2, pp. 151-160.

15. Kurniawan, H. 2016. Efektifitas Pembelajaran Problem Solving dan Investigasi Terhadap Keterampilan Berpikir Kritis Matematis Berbantuan Google Classroom. Jurnal Pendidikan Surya Edukasi (JPSE)., Vol 2, No 1, pp. 56-67.

16. Widodo, T., dan S. Kadarwati. 2013. Higher Order Thinking Berbasis Pemecahan Masalah untuk Meningkatkan Hasil Belajar Berorientasi Pembentukkan Karakter Peserta Didik. Cakrawala Pendidikan., Vol 32, No 1, pp. 161- 171.

17. Sudarmo, M. N. P., \& Mariyati, L. I. 2017. Kemampuan Problem Solving. Jurnal Psikologi., Vol 2, No 1, pp. 38-51.

18. Živkovic, S. 2016. A model of critical thinking as an important attribute for success in the 21st century. Procedia - Social and Behavioral Sciences., Vol 23, No 2, pp. 102108.

19. Djamarah, S.B., dan A. Zain. 2010. Strategi Belajar Mengajar. Jakarta: PT Rineka Cipta.

20. Gulo, W. 2002. Metode Penelitian. Jakarta: PT. Grasindo.

21. Arends, R. 2012. Learning to Teach. New York: Mc Graw Hill.
22. Polya, G. 1973. How to Solve It. A New Aspect of Mathematical Method. New Jersey: Princenton University Press.

23. Banilower, E., Smith, P.,S., Weis, I. R. \& Pasley, J.D. 2006. The status of K-12 Science Teaching in the United Sttes: Result from a National Observation Survey. Greenwich CT: Information Publishing.

24. Anisah. 2018. Pengembangan Bahan Ajar Berbasis HOTS untuk Meningkatkan Kemampuan Pemecahan Masalah Matematis Mahasiswa. Jurnal Matematika KreatifInovatif., Vol 9, No 2, pp. 191-197.

25. Mahanal, S. 2019. A Learning Model to Develop Critical Thinking Skills for Students with Different Academic Abilities. International Journal of Instruction., Vol 12, No 2, pp. 418-434.

26. Quellmalz, E. S. 1985. Needed: Better Methods for Testing Higher Order Thinking Skills. Educational Leadership., Vol 43, No 2, pp. 29-35.

27. King, F.J, Goodson, L., \& Rohani, F. 2006. Contribution of Logical Thinking Ability to Students' Achievement in Three Level of Representations in Chemical Dynamic Materials. Jurnal Penelitian dan Pembelajaran IPA., Vol 4, No 2, pp. 116126.

28. Brookhart, Susan M. 2010. Assess Higher Order Thinking Skills In Your Classroom. Virginia USA: ASCD.

29. Anderson, Lorin W And Krathwhol, David R. 2001. A Taxonomy For Learning Teaching, And Assessing. New York: Longman.

30. Model Norris, S. P., \& Ennis, R. H. 1989. Evaluating Critical Thinking. Pacific Grove, CA: Critical Thinking Press \& Software.

31. Wahid, A. H. 2018. Integrasi Higher Order Thinking Skills (HOTS) dengan Creative Problem Solving. Jurnal Program Studi PGMI., Vol 5, No 1, pp. 82-98.

32. Wibawa, R. P. 2019. Peran Pendidikan Berbasis Higher Order Thinking Skills pada Tingkat Sekolah Menengah Pertama di Era Society 5.0 Sebagai Penentu Kemajuan Bangsa Indonesia. Jurnal Ilmiah Ekonomi., Vol 7, No 2, pp. 137-141. 
33. Kurniati, D. 2016. Kemampuan Berpikir Tingkat Tinggi Siswa SMP di Kabupaten Jember dalam Menyelesaikan Soal Berstandar PISA. Penelitian dan Evaluasi Pendidikan., Vol 20, No 2, pp. 142-155.

34. Firman, H. 2018. Contribution of Logical Thinking Ability to Students' Achievement in Three Level of Representations in Chemical Dynamic Materials. Jurnal Penelitian dan Pembelajaran IPA. Vol 4, No 2, pp. 116-126.

35. Winataputra, Udin. 2007. Teori Belajar dan Pembelajaran. Jakarta: Pusat Penerbitan Universitas Terbuka

36. Sujana, Nana. 2009. Penilaian Hasil Belajar. Bandung: Rossda Karya

37. Djaali. 2008. Psikologi Pendidilan. Jakarta: Bumi Aksara

38. Mayasari, R. \& Rabiatul A. 2015. Pengaruh Model Pembelajaran Berdasarkan Masalah pada Pembelajaran Biologi Terhadap Hasil Belajar dan Keterampilan Berpikir Tingkat Tinggi Di SMA. Jurnal Pendidikan Biologi Indonesia. Vol 1, No 3, pp. 255-262.

39. Harta, J. 2017. Pengembangan Soal Esai Berbasis HOTS untuk Menyelidiki Keterampilan Pemecahan Masalah Siswa SMA. Jurnal Penelitian. Vol 21, No 1, pp. 62-69.

40. Mahfuzah, B. A., Munzil., \& Utomo, Y. 2018. Efektifitas GDL (Guided Discovery Learning) dan Problem Solving Terhadap KBK (Keterampilan Berpikir Kritis) dan HOTS (Higher Order Thinking Skills). Jurnal Pendidikan. Vol 3, No 6, pp. 739-744.

41. Nisak, F., Gusnedi, \& Putra, A. 2018. Penggunaan Bahan Ajar Berorientasi Pemecahan Masalah Terhadap Pencapaian Higher Order Thinking Skills (HOTS) Siswa dalam Pembelajaran Fisika di Kelas X. Pillar of Physics Education. Vol 11, No 1, pp. 2532.
42. Daryanti, S., Indra S., \& Dedy H. 2019. Pengaruh Pembelajaran Model Problem Solving Berorientasi Higher Order Thinking Skills Terhadap Hasil Belajar Fisika dan Kemampuan Pemecahan Masalah. Jurnal Kumparan Fisika. Vol 2, No 2, pp. 65-72.

43. Sudjana. 1996. Metode Statistika. Bandung: Tarsito.

44. Tambunan, H. 2019. The Effectiveness of the Problem Solving Strategy and the Scientific Approach to Student Matematical Capabilities in Higher Order Thinking Skills. International Electronic Journal of Mathematcs Education. Vol 14, No 2, pp. 293-302.

45. Sumantri, M. S., \& Whardani, P. A. 2017. Relationship between Motivation to Achieve and Professional Competence in the Performance of Elementary School Teachers. International Education Studies, Vol 10, No 7, pp. 118-125.

46. Permendikbud 81A. 2013. Standar Proses Pendidikan Dasar dan Menengah. Jakarta: Kemendikbud.

47. Nabila, H. 2018. Efektivitas Problem Solving Materi Asam Basa dalam Meningkatkan HOTS ditinjau dari Kemampuan Akademik. Jurnal Pendidikan dan Pembelajaran Kimia., Vol 1, No 1, pp. 1-15.

48. Sardin. 2018. Pengaruh Metode Pembelajaran Problem Solving Terhadap Higher Order Thinking Skills (HOTS). Jurnal The Original Research of Mathematics., Vol 3, No 1, pp. 81-91.

49. Azzahra, W. 2020. Pengaruh Penerapan Model Problem Solving Terhadap Keterampilan Berpikir Tingkat Tinggi dan Aktivitas Belajar Peserta Didik. Bioeducation Journal., Vol 4, No 1, pp. 20-28.

50. Bruner, J. S. 1966. Toward a Theory of Instruction. Cambridge: Harvad University. 